\title{
Unusual cause of a left hypochondria pain: pedunculated giant haemangioma of the liver
}

\author{
Sami Kouki, ${ }^{1}$ Imen Helal, ${ }^{1}$ Mehdi Ben Lassoued ${ }^{2}$
}

${ }^{1}$ Radiology Department, Military Hospital of Tunis, Faculty of Medecine, University of Tunis El Manar, Tunis, Tunisia

${ }^{2}$ Emergency Department, Military Hospital of Tunis, Faculty of Medecine, University of Tunis El Manar, Tunis, Tunisia

Correspondence to Sami Kouki, koukisemi@yahoo.fr

Accepted 19 July 2019

\section{DESCRIPTION}

A 26-year-old woman with no medical or surgical history presented with abdominal pain in the left hypochondria without any other symptoms. The patient underwent ultrasound that showed a well-defined mass of the left hypochondria, heterogeneous measuring $9 \mathrm{~cm}$. The lesion seems independent of the spleen and liver. We completed by an MRI of the abdomen. Contrast-enhanced MRI demonstrated a mass of the left hypochondria, well demarcated, measuring $9 \mathrm{~cm}$ with low signal of intensity on $\mathrm{T} 1$ (figure 1) and a high intensity on T2 (figure 2) with peripheral progressive nodular enhancement, which progresses centripetally in delayed images (figure 3 ). The homogenisation of the lesion was seen on late sequences. A pedicle connected the lesion to the segment II of the liver. A second lesion measuring $2 \mathrm{~cm}$ with similar MRI feature is located in the segment VII of the liver. Otherwise, the liver was homogeneous. These aspects are consistent with the diagnosis of pedunculated giant haemangioma of the liver extending in the left hypochondria.

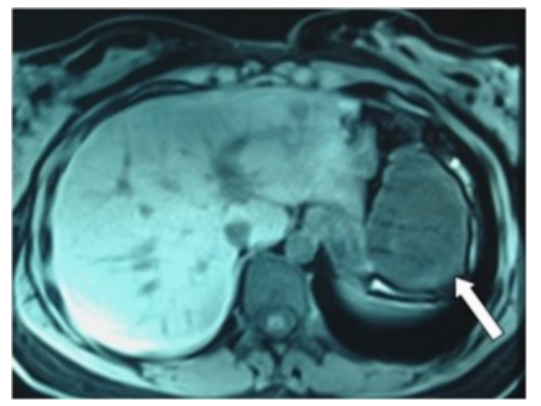

Figure 1 MRI, transversal plane, well-defined left hypochondria with low signal on T1-weighted image (arrow).

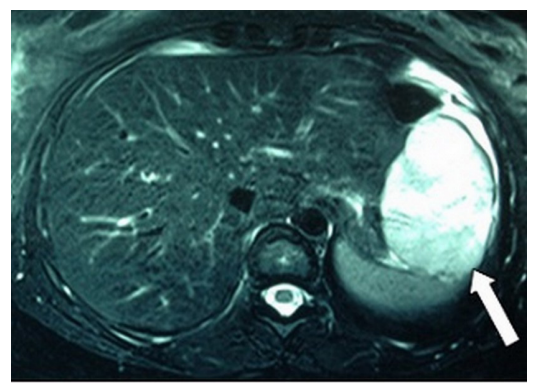

Figure 2 MRI, transversal plane, well-defined left hypochondria with high signal on T2-weighted image (arrow).

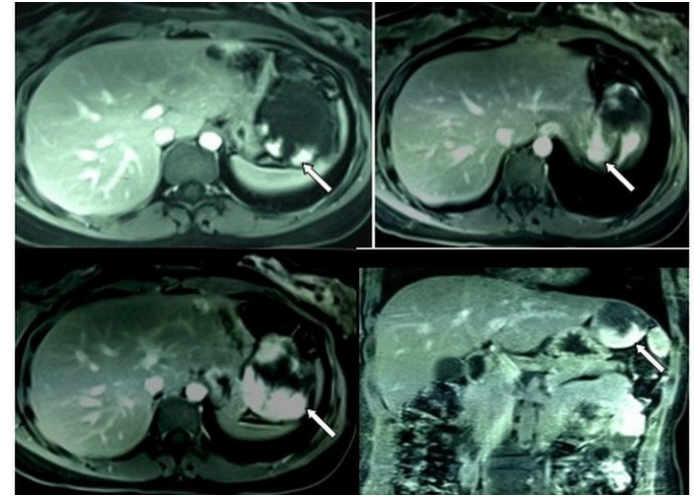

Figure 3 MRI, transversal and coronal planes, gadolinium-enhanced T1-weighted image. Welldefined mass with peripheral progressive centripetally enhancement originating from segment II of the liver (arrow).

Pedunculated haemangiomas with exophytic growth are extremely rare. To date, only 20 cases of such pedunculated giant haemangiomas of the liver have been reported in the literature. ${ }^{1}$

In cases of typical haemangiomas, imaging modalities are highly reliable for diagnosis, especially MRI, which has a sensitivity and specificity of greater than $90 \% .^{2}$ According to the literature, ultrasound, CT and MRI detection rates for hepatic haemangiomas are 57-90, 5\%,73\%-92.2\% and $97 \%$, respectively. ${ }^{3}$

Learning points

- Pedunculated giant haemangioma of the liver is extremely rare.

- Exophytic growth of hepatic haemangioma especially in left hypochondria is rare.

- Pedunculated hepatic haemangioma with exophytic growth should be evoked in case of left hypochondria mass.

Acknowledgements The authors would like to acknowledge $\mathrm{Pr}$ Ben Abdallah, Head of Radiology Department.

Contributors SK: patient observation. IH: figures. MBL: bibliography.

Funding The authors have not declared a specific grant for this research from any funding agency in the public, commercial or not-for-profit sectors.

Competing interests None declared.

Patient consent for publication Obtained.

Provenance and peer review Not commissioned; externally peer reviewed. 


\section{Images in...}

\section{REFERENCES}

1 El Hajjam M, Lacout A, Marzouqi MK, et al. Pedunculated hepatic hemangioma masquerading as a peritoneal tumor: a case report. Pol J Radiol

2016:81:51-3.
2 Moody AR, Wilson SR. Atypical hepatic hemangioma: a suggestive sonographic morphology. Radiology 1993;188:413-7.

3 Sun JH, Nie CH, Zhang YL, et al. Transcatheter arterial embolization alone for giant hepatic hemangioma. PLoS One 2015;10:e0135158.

Copyright 2019 BMJ Publishing Group. All rights reserved. For permission to reuse any of this content visit

https://www.bmj.com/company/products-services/rights-and-licensing/permissions/

BMJ Case Report Fellows may re-use this article for personal use and teaching without any further permission.

Become a Fellow of BMJ Case Reports today and you can:

- Submit as many cases as you like

- Enjoy fast sympathetic peer review and rapid publication of accepted articles

- Access all the published articles

- Re-use any of the published material for personal use and teaching without further permission

\section{Customer Service}

If you have any further queries about your subscription, please contact our customer services team on +44 (0) 2071111105 or via email at support@bmj.com.

Visit casereports.bmj.com for more articles like this and to become a Fellow 